\title{
Vito Mancuso in English: Presenting the Thought of a Contemporary Radical Catholic Theologian and Philosopher to the English-Speaking World
}

\author{
Corneliu C. Simuț \\ Emanuel University, Romania \\ University of Pretoria, South Africa
}

\begin{abstract}
Vito Mancuso is an Italian theologian and philosopher of religion, who deflects from traditional Catholic theology with the intention to draft a new perspective on how theology should be understood, not only in the academy but also in public and private life. This is why he resorts to Hegelian concepts, which redefine most of what traditional theology has held dear throughout history, with a specific focus on how to turn theology from ideas defined by divinity to notions explained by anthropology. A prolific writer, Mancuso has written almost one book per year for the past decade or so, while he is also very active in the media by giving interviews and writing short articles for famous Italian newspapers, such as La repubblica. In all his endeavors, Mancuso attempts to provide contemporary society with a view of God which is essentially human and profoundly anthropologic in nature in the hope that such an understanding of God will make sense of humanity's current issues and struggles. Despite the rather controversial fame he acquired in Italy, Mancuso is virtually unknown to the English-speaking public, so this paper is an attempt to present him to those who are not only versed in English theology and philosophy of religion, but also to those who still believe that theology and philosophy of religion may be valuable instruments for the information and transformation of today's society.
\end{abstract}

\section{Keywords}

God, laity, materiality, spirituality, authenticity

\section{From Priesthood to Laity}

Vito Mancuso is technically a theologian for three main reasons. First, because he is academically trained in the field of theology, having obtained specific theological degrees from papal schools, such as the Baccalaureatus in
Theology from the Theological Faculty of Northern Italy (Facoltà Teologica dell'Italia

\footnotetext{
Corresponding author:

Corneliu C. Simuț

Email: corneliu.simut@emanuel.ro
} 
Settentrionale di Milano) in Milan, the Licence/ Bachelor in Theology from the Pontifical Theological Faculty Saint Thomas Aquinas of Southern Italy (Pontificia Facoltà Teologica dell'Italia Meridionale San Tommaso d'Aquino) in Naples, and the Doctorate in Theology from the Pontifical Lateran University (Pontificia Università Lateranense) in Rome. Second, he considers himself a theologian and, since he was raised and trained in Catholic schools, he sees himself as a Catholic theologian, ${ }^{1}$ although not along the lines of traditional Catholicism or within the boundaries of pontifical approval. ${ }^{2}$ Third, he does talk and write a lot about God, which should qualify him to stand before his readers, viewers, and listeners as a person who made a profession out of his theological training. This has certainly become clear to the naked eye for the past decade, when Mancuso kept providing the media with all sorts of "breaking news"-related more or less to theology, but surely of interest to the Italian public $^{3}$ - either by writing and publishing various materials or offering interviews for radio and television channels. ${ }^{4}$

Mancuso, however, is not the traditional Catholic theologian one may expect and this is again for three main reasons. First, although

\footnotetext{
${ }^{1}$ For details, see Vito Mancuso, Il dolore innocente. L'handicap, la nature e Dio (Milano: Mondadori, 2002), vii-viii. Mancuso is also seen as an "influential Catholic" by Letizia Paolozzi and Alberto Leiss. See Letizia Paolozzi, Alberto Leiss, La paura degli uomini. Maschi e femine nella crisi della politica (Milano: Saggiatore, 2009), 70.

${ }^{2}$ For instance, Mancuso was extremely critical of Benedict XVI during his pontificate because, in his view, the pope should not be invariably negative in his statements. What actually bothered Mancuso was that the pope says "always and only "no"" instead of being a bit more positive from time to time. See John Follain, 'Crowds Shrink for 'Bland' Benedict, the Pope Who Only Says No', The Sunday Times, January 4, 2009, 22.

${ }^{3}$ See Raffaele Cardone, 'Calendario editorial: Un decoder per il libro (batteries not included)', in Vittorio Spinazzola (ed.), Tirature 2010. Autori, editori, pubblico (Milano: Saggiatore, 2010), 202-215, on 205.

${ }^{4}$ For details about Mancuso's activity, see <www. vitomancuso.it>.
}

he was ordained priest at 23 , he renounced his priestly vows a year later, when he formally became a lay person. Thus, since he continues to occupy his activities with theology, he is a lay theologian. Second, having obtained the pope's approval, he married a civil engineer and he is now a father of two; consequently, he is not only a lay theologian, but a married theologian. Third, he openly disapproves of, and therefore attacks, some of the basic beliefs of traditional Catholicism, but in doing so he also dismisses some of Christianity's main doctrines. For instance, Mancuso cannot accept the fact that human beings are created directly by God himself in the sense that God places a soul within the human being at the moment of physical conception. ${ }^{5}$ At the same time, he staunchly criticizes the doctrine of original sin; in this respect, he cannot accept that original sin should be defined as enmity with God and that each baby is born with original sin because of Adam's transgression. ${ }^{6}$ Another classical Christian doctrine dismissed by Mancuso is the resurrection of the dead, which of course goes hand in hand with the doctrine of God's final judgment of humanity and that of man's eternal existence either in heaven or in hell. ${ }^{7}$ When it comes to hell, he also denies that eternal damnation is possible and that those condemned for eternity are forever separated from God in body and soul. ${ }^{8}$ Once Mancuso establishes what he cannot accept, he continues by pointing to the things he is willing to embrace, such as: first, the primacy of human spirituality which is visible in the practical application of love in society and human interaction; ${ }^{9}$ second, the necessity

\footnotetext{
${ }^{5}$ Mancuso, Il dolore innocente, 17-18.

${ }^{6}$ Mancuso, Il dolore innocente, 150.

7 Vito Mancuso, Rifondazione della fede (Milano: Mondadori, 2005), 260-2.

${ }^{8}$ Mancuso believes only in man's union with God, which is in fact man's union with himself. See Mancuso, Rifondazione della fede, 257-9.

${ }^{9}$ In order for man to do this, he must work, a vital concept in Mancuso. See Vittorio Possenti, Il nuovo principio persona (Roma: Armando Editore, 2013), 164.
} 
to embrace a new perspective on the world as a material reality, which is not created by God, but rather creates itself through the actions of human beings so God is in the world, in the materiality of nature and of the human being; and third, an immanent soteriology based on an exclusively human Christ, ${ }^{10}$ meaning that men and women can find meaning for their mortal lives and finite existence if they do what Jesus told them to do, namely lead lives characterized by peace, justice, and-above all-love, the very meaning of the human being. ${ }^{11}$

Practically, Mancuso is not a theologian, but a philosopher or - as a concession to his own confession that he is indeed a theologiana philosopher of religion. ${ }^{12}$ This is because, although he talks about God, he does so because he is interested in the human being, so in his thought God is merely an excuse for delving into the realities of human life, to the point where God's love serves as model for man's love and God's justice translates as human justice. In Mancuso, God is a pretext for his desire to present the human being in a new light, a light which is devoid of the traditional doctrine of God as a supreme, uncreated, and ontologically real being, but still imbued with the idea of God, a notion which provides mortal humans with a sense of permanence and meaning in a world of matter and death, as perceived by what Mancuso considers to be the contemporary atheistic society. ${ }^{13}$ God is not something or somebody Mancuso is willing to accept as existing, or even living beyond this world or beyond this universe; on the contrary, the God Mancuso

\footnotetext{
${ }^{10}$ For details about the connection between creation and Jesus Christ in Mancuso, see Corneliu C. Simuț, 'The Theology of Creation in Vito Mancuso's Radical Theology', in Acta Theologica 31.1 (2011): 138-55, on 142.

${ }^{11}$ Mancuso, Il dolore innocente, 88.

12 This is why Mancuso's thought was also described as "theo-philosophy". See Fabio Brotto, Rileggendo Simone Weil (Firenze: Il Covile, 2011), 58.

${ }^{13}$ See also Orlando Franceschelli, Darwin e l'anima. L'evoluzione dell'uomo e I suoi nemici (Roma: Donzelli Editore, 2009), 101-2.
}

is ready to accept must remain confined within the boundaries of this world either as the world itself in more general terms or as the human being in particular. In Mancuso's thought, God cannot and should not escape humanity; God must be at the disposal of human beings. It is not God who created men and women as in traditional theology; it is men and women who created God. This is why Mancuso's thought is better described as philosophy of religion, not theology: because the main character of his narrative is not God, but the human being presented in terms which resemble God. Thus, man - not God - is the creator, promotor, and defender of love, peace, and justice, an idea which illustrates Mancuso's personal move from priesthood to laity and then from laity to philosophy. God is no longer "out there", outside the human being, but "in here", within men and women; God is no longer a being, but an action - this is why, in Mancuso, the "presence of God" is established through the doing of the good. Wherever the good is done, God is also there. $^{14}$

In disseminating his beliefs, Mancuso is extremely active, so he not only writes a lot, but he has also established a consistent presence in the media. Having published over ten booksof which eight as a single author-Mancuso is definitely a professional writer, ${ }^{15}$ but in addition to this he also writes for newspapers (especially in La repubblica),${ }^{16}$ gives interviews, and attends a wide range of conferences throughout Italy. He appears to be in high demand not only

\footnotetext{
${ }^{14}$ Mancuso, Rifondazione della fede, 177-8.
}

${ }^{15}$ As a writer, Mancuso is both controversial and appreciated, but never ignored. See Angelo Cannatà, Eugenio Scalfari e il suo tempo. Un viaggio nelle idee di Scalfari e nei fatti, gli avvenimenti più importanti della recente storia d'Italia (Milano: Mimesis Edizioni, 2010), 303.

${ }^{16}$ In La repubblica, Mancuso launched his famous thesis that unlike other Western countries, Italy lacks a civil religion which is supposed to connect the individual to society in a responsible way. See Roberto Garaventa, Religiosità senza dogmi. Ambiguità e prospetticità delle religioni storiche (Napoli: Orthotes Editrice, 2012), 17, n. 60. 
because he aggressively promotes his views in any way he can - and I mean this in a positive way-but he is also in a position of directly influencing others since he currently serves as professor of the history of theological doctrines at the University of Padova, having taught modern and contemporary theology for many years at the Faculty of Philosophy within San Raffaele University of Milano. ${ }^{17}$

\section{From God to Man}

The first book written by Mancuso which caught my eye was Hegel Theologian (1996), a project based on Mancuso's doctoral dissertation that sets him firmly within the limits of modernity and outside the boundaries of theological traditionalism. Two concepts saliently emerge from the beginning in Hegel as presented by Mancuso: freedom ${ }^{18}$ and truth, ${ }^{19}$ which both appear recurrently in Mancuso's books. Mancuso portrays Hegel as the fundamental defender of God's knowledge despite the spirit of modernity, which is essentially subjective. ${ }^{20}$ Hegel himself is a modern so this entire thought is based on the idea of subjectivity; nevertheless, Mancuso insists, Hegel wants to know God, not man. The subjectivity of the human being should be directed towards God, not towards man, so if one is to believe Mancuso, Hegel's basic desire was to discover God, not man. In order for Hegel to know God, he needed to rediscover the idea of freedom, which cannot be detached from that of truth. ${ }^{21}$

\footnotetext{
${ }^{17}$ See also Corneliu C. Simuț, Essentials of Catholic Radicalism. An Introduction to the Lay Theology of Vito Mancuso (Frankfurt am Main: Peter Lang, 2011), 16-17.

${ }^{18}$ For details, see Simuț, Essentials of Catholic Radicalism, 119.

${ }^{19}$ Simuț, Essentials of Catholic Radicalism, 163.

${ }^{20}$ More about Hegel's approach to subjectivity in Dale M. Schlitt, Hegel's Trinitarian Claim. A Critical Reflection (Albany, NY: State University of New York Press, 2012), 10.

21 The connection between freedom and God in Hegel is explained in William Desmond, Hegel's God. The Counterfeit Double? (Aldershot: Ashgate, 2003), 143-4.
}

Hegelian freedom though, Mancuso points out, must be realized but also reign supreme within the realm of humanity. Man, however, cannot know God in an objective way as a being outside himself; in order for man to know God, he needs to look inside his own self, so the knowledge of God in Hegel is spiritual. ${ }^{22}$ To be more exact, the knowledge of God resembles the knowledge of the physical world because they are both spiritual. Thus, Mancuso explains that, in Hegel, knowing God is an enterprise of the spirit which works with man's reason, so the knowledge of God is eventually conceptual. The problem, nevertheless, has to do with the actual location of God; where is God so that man should be able to know him? One cannot go directly to God, so - as Hegel suggests - one should look within oneself in order to search for truth. ${ }^{23}$ Thus, man finds within himself an utter contradiction or antagonism, namely that he can conceive the idea of eternity and absoluteness which best defines the notion of God, but at the same time he has to look inside his own self for ways to know this eternity and absoluteness. ${ }^{24}$

This is why Hegel attempts to cancel this antagonism between God and man, between God as object and man as subject. The solution, as Mancuso points out, is the idea of reconciliation which attempts to present the absoluteness of God as the essence of humanity, ${ }^{25}$ in other words, the traditional God of

\footnotetext{
${ }^{22}$ For details about the knowledge of God in Hegel, see Thomas A. Lewis, Religion, Modernity, and Politics in Hegel (Oxford: Oxford University Press, 2011), 145-6.

${ }^{23}$ Consequently, in Hegel, the knowledge of God is mediated through the reality of the natural world - in this case, the human being. See Bernard Cullen, 'Hegel on the Human and the Divine, in the Light of the Criticisms of Kierkegaard', in William Desmond (ed.), Hegel and His Critics: Philosophy in the Aftermath of Hegel (Albany, NY: State University of New York Press, 1989), 93-103, on 101.

${ }^{24}$ Vito Mancuso, Hegel teologo e l'impardonabile assenza del «Principe di questo mondo» (Casale Monferrato: Piemme, 1996), 22-9.

${ }^{25}$ More about Hegel's idea of reconciliation in Charles Taylor, Hegel (Cambridge: Cambridge University Press, 1975, reprinted 1999), 550.
} 
pre-modern times, often presented as an object or rather "the" Object par excellence, becomes the modern human being whose capacity to investigate reality-both external, physical, and material as well as internal, metaphysical, and spiritual - is fundamentally based on his capacity to think rationally. Hegel's reconciliation leads to the principle of identity; ${ }^{26}$ there is a basic coincidence between what we used to know as God and what we now know as the human being. Thus, God is man and man is God, the object became the subject and the subject finally understood that he is the object. ${ }^{27}$ Such an overlapping between God and man is possible, as Hegel shows, through Jesus Christ, the man who presented himself in divine terms and whom people perceived as the God-man. The spirit of God is shown to be the spirit of Christ and since every human being shares in the spirit of Christ, it means that all men and women have the spirit of God precisely because Christ claimed to have had the spirit of God within him. Mancuso's intention is to turn God into man and he does precisely that by putting together the absoluteness of God and the finitude of man through the mediation of the notion of spirit. $^{28}$

When these distinctly Hegelian ideas are taken over by Mancuso, his persistent theological endeavor gradually becomes a philosophy of religion, especially as his focus shifts from God to man. ${ }^{29}$ Mancuso uses Hegel's principle of identity and the idea of reconciliation to build his thought on the idea that there is no distance between God and man; in fact, the two are the same reality. God and man share not only the same spirit, but also the same being, so man is

\footnotetext{
${ }^{26}$ For details about Hegel's concept of identity, see Frederick Beiser, Hegel (New York, NY: Routledge, 2005), 146-7.

${ }^{27}$ See also Patricia Jagentowicz Mills, 'Hegel's Antigone', in Jon B. Stewart (ed.), The Phenomenology of Spirit Reader: Critical and Interpretative Essays (Albany, NY: State University of New York Press, 1998), 243-71, on 266.

${ }^{28}$ Mancuso, Hegel teologo, 30-8.

${ }^{29}$ See Simuț, Essentials of Catholic Radicalism, 34.
}

a subject who realizes his complete autonomy and consequently perceives himself as absolute criterion for the affairs of this world, but in doing so he spiritually assesses his materiality as part of the natural world..$^{30}$ There is therefore a clear connection between theology or religion and truth; since God becomes man, the object of theology overlaps with the object of man's quest for truth. Once man realizes that he knows God as being his very own self, one can say that man has already achieved the knowledge of God and once God is known through religionwhich is through man's reason as applied to religious concepts - truth is also attained. For Mancuso, this means that Christianity is no longer an exclusivist religion; on the contrary, it is fundamentally an inclusivist spirituality which allows for the traditional dogma of salvation to be read as philosophy of history. Thus, being saved has nothing to do with accepting certain doctrines and belonging to certain churches; being saved means accepting the idea that God is no other than man himself and that he can be known through reason. Once I know God as being my own self, then my religion opens towards the welfare of the entire world, since I am now enabled to embrace everybody in the love, peace, and justice preached and applied by Jesus as divine virtues. ${ }^{31}$ Salvation becomes history as much as God becomes man; such a knowledge though, Mancuso insists, is available to everybody because the distance between God and man, as well as the contradiction between God and man have already been reconciled with man's capacity to investigate the external and internal realities of the material

\footnotetext{
${ }^{30}$ So there is in Mancuso a primacy of spirituality over materiality but only in epistemology. See also Nadia Urbinati, Prima e dopo. La brutta china della democrazia italiana (Roma: Donzelli Editore, 2011), 125.

31 This is why Mancuso defends the idea of a civil religion. See Vito Mancuso, 'La religione civile che manca all'Italia', in La repubblica, January 13, 2009, 1. Mancuso's proposal was noticed and advertised in the English-speaking world by Pasquale Annicchino, 'Laïcité as Civil Religion. An Italian American Perspective', The George Washington International Law Review 41.4 (2010): 817-26, on 818.
} 
world in a spiritual way. ${ }^{32}$ In Mancuso, being saved means being aware that we all live in a material and physical world, which can nevertheless be understood in spiritual terms. For as long as love, justice, and peace are promoted as values that cancel the ontological distance between God and man for the main and only purpose of reconciling God and man in one and the same spirit and being. ${ }^{33}$

These ideas can be found in every book Mancuso has written ever since, but the most important for the purpose of having his thought described briefly and, at the same time, comprehensively, are his two main bestsellers: The Soul and Its Destiny (2007) and I and God (2011), which — against all odds and for a bunch of theological books - enjoyed a tremendous amount of success in Italy.

\section{From Materiality to Spirituality}

Having sold over one hundred thousand copies - an immensely incredible number for a theological book these days - The Soul and Its Destiny was published a decade after Hegel Theologian, a period during which Mancuso had enough time to clarify and crystalize his thought. He remains staunchly Hegelian in his convictions because, once he abandoned the metaphysical, transcendent, personal, and ontologically real God of traditional theology in Hegel Theologian, there was no way in which he could get him back in his later productions. ${ }^{34}$ On the contrary, Mancuso makes it clear that God can no longer be viewed in theistic and personalistic terms; God is not a supernatural

\footnotetext{
32 Fore details about the availability of salvation for everybody in Mancuso, see Roberta de Monticelli, L'ordine del cuore. Etica e teoria del sentire (Milano: Garzanti Libri, 2012), 6 .

${ }^{33}$ Mancuso, Hegel teologo, 384-90.

${ }^{34}$ More about Hegel's influence on Mancuso in Marcello Paradiso, Nell 'intimo di Dio. La teologia trinitaria di Hans Urs von Balthasar (Roma: Città Nuova Editrice, 2009), 293, n. 4.
}

being who created the world, but a concept which works within the world. ${ }^{35}$ The world is essentially material and physical and it is within this world that God works as an "ordaining principle" which is essentially impersonal, not personal like in traditional theology. ${ }^{36}$ Having been aided by Hegel, Mancuso brought God down to earth and turned him from a personal supernatural being into an impersonal natural principle, so Mancuso's God is not heavenly (in the sense that he exists beyond the materiality of creation), but worldly (since he exists as principle in the materiality of the natural world). Although his thought took a decisive turn towards philosophy, Mancuso tries his best to remain within the linguistic boundaries of theology because, as he explains, the impersonal ordaining principle of the world, which he calls "God" is described by the Bible through the concept of wisdom. ${ }^{37}$ Thus, wisdom-evidently human wisdomacts upon the materiality of the world which is characterized by "chaotic energy".38 When using the chaotic energy of the material world, wisdom begins to create things, which means that man has the spiritual capacity to create, a reality which was described in traditional theology through the doctrine of creation. This is how man grows from materiality to spirituality. ${ }^{39}$

\footnotetext{
${ }^{35}$ For details about Mancuso's criticism of traditional theology, see the whole chapter 1 of Marcello Veneziani, Dio, patria e famiglia dopo il declino (Milano: Mondadori, 2012).

${ }^{36}$ A key element which pushed Mancuso towards atheistic theology and the redefinition of God in impersonal terms is the silence of the Catholic church concerning the sexual abuses of children by priests in countries like Ireland. see Giulio Giorello, Senza Dio. Del buon uso dell'ateismo (Milano: Longanesi, 2010), 14-15.

${ }^{37}$ See the chapter written by Giulio Giorello, 'Libertarismo ovvero radicalismo senza radici', in Dario Antiseri and Giulio Giorello, Libertà. Un manifesto per credenti e non credenti (Milano: Bompiani 2008).

${ }^{38}$ More about the idea of energy in Mancuso can be found in Lionello Sozzi, Gli spazi dell'anima (Torino: Bollati Boringhieri Editore, 2011), 10-12.
}

39 Vito Mancuso, L'anima e il suo destino (Milano: Raffaello Cortina Editore, 2007), 303. 
There is no God who creates in Mancuso, only man is able to use his wisdom and, in doing so, create material or spiritual things within the physical world of nature. Since, however, in Hegel man is described as God one should feel free to say that 'God' (meaning man) created the world, which actually means that man used his wisdom to mold the matter of this world in a creative way. Mancuso sees man's capacity to create as a "divine" reality whose purpose is to produce freedom. This is why, in Mancuso, the ordaining principle of the world - or God for those who prefer this term - must be essentially impersonal. Freedom can exist only if the world is governed by an impersonal force, Mancuso contends, ${ }^{40}$ otherwise, if the world had been created and governed by a supreme being, who is ontologically real, transcendent, metaphysical, different from the human being, and personal, freedom would not have been possible. Mancuso is convinced that traditional theology, which believes in God as supernatural and personal being, is highly totalitarian and generates political systems which are equally prone against personal freedom. Religion and politics go hand in hand in Mancuso precisely because religion does not come from above, or from outside the material world, but from within the physicality of man's material existence in the world. ${ }^{41}$ The world, however, is characterized by the existence of energy which is essentially chaotic. This energy works in many ways and man's evolution is just one of them. Once man has evolved into a rational being, this chaotic energy can be said to have reached a point when it became divine, in the sense that man himself was able to create something by using his wisdom. Man though exists in the world as body and soul, both being material manifestations of

${ }^{40}$ In this respect, Mancuso differs from Hegel because the Absolute Spirit in Hegel is eventually the human being who is personal. See Quentin Lauer, SJ, Essays in Hegelian Dialectic (Bronx, NY: Fordham University Press, 1977), 7.

\footnotetext{
${ }^{41}$ For a brief though thoughtful analysis of Mancuso's interest in religion and politics, see Roberto Corsi, Facebook: figure e figurucce della decadenza (Roma: Armando Editore, 2009), 36-8.
}

the world's energy. ${ }^{42}$ It is important to notice that in Mancuso the body and the soul are equally material and physical. Spirituality is only a feature of the material soul, which means that since man has the rational faculty to create things he can be considered divine. In acting like "God", man uses his wisdom (or his reason) to ordain and arrange the chaotic energy of the world into things which make sense both materially and spiritually. ${ }^{43}$ Thus, man creates things, but he also creates concepts; both things and concepts are essentially material since they originate in the material reality of man's existence as physical organism powered by energy and capable of producing work. ${ }^{44}$ At the same time, though, both can be said to have a spiritual meaning within the larger context of man's existence in the world precisely because man was able to create them as a result of his wisdom and then use them rationally for the various purposes of his existence in the world. ${ }^{45}$

Man is a material being; he is a material reality which works in the physicality of the world in a creative way thanks to his capacity to think rationally. When man starts to work in the world, he uses his freedom and becomes spiritual. In fact, as Mancuso points out, when he creates man becomes spirit; the material body becomes a spiritual soul, so the essence of man's soul - although spiritual because it cannot be seen - is fundamentally material because it originates in the body. ${ }^{46}$ The soul, however, is the spiritual expression of man's capacity to create in freedom. ${ }^{47}$ When man creates he

\footnotetext{
${ }^{42}$ See also Francesco P. Firrao, Origini. Nascita della scienza moderna e nuove prospettive: laboratori didattici, ipotesi di percorso (Firenze: Leo S. Olschki, 2009), 125.

${ }^{43}$ For details about Mancuso's theory of creation, see Simuț, Essentials of Catholic Radicalism, 100.

${ }^{44}$ Compare Possenti, Il nuovo principio persona, 164.

${ }^{45}$ Mancuso, L'anima e il suo destino, 304-5.

46 See also Raniero Seri, Temi, problemi e aspetti del rapporto tra Dio e l'uomo (Roma: Armando Editori, 2013), 85.

47 The connection with Hegel in this respect is evident again. See Giorgio Sgubbi, L'intelligenza del mistero. Dialogo con Eberhard Jüngel (Roma: Città Nuova Editrice, 2000), 44, n. 123
} 
uses the chaotic energy of the world through wisdom; man creates by using his reason and when he does that he becomes spiritual. Man acquires a soul whenever he uses his reason to create something out of the chaotic energy of the world; in other words, the soul is man's free energy which ordains the chaotic energy of the material world. The human soul is characterized by freedom because he is not only able to use his reason; he actually uses his reason in freedom and, in doing so, he not only creates material and spiritual things, but also builds his own "soul". ${ }^{48}$ Whenever he creates, man takes a step towards the knowledge of his own self and the world. Once he knows himself as being in the world, man's soul moves towards morality, which is the source of the good and justice, both imperatives of man's spiritual life. ${ }^{49}$

\section{From Authority to Authenticity: Concluding Remarks}

Mancuso's second bestseller is I and God (2011) which I shall use to draw some concluding assessments concerning his entire thought. The title $I$ and God is somehow misleading because it should have been I as God. Since the ontologically real, personal, transcendent, and metaphysical God of traditional theology is no longer to be trusted, as Mancuso recommends, simply because he does not exist - and he does not exist because man concluded that there is an overlapping between his own being and Godman must rethink what he believes. ${ }^{50}$ Belief in a supernatural God is out of the question and since God is actually man's own being in the

48 This can be understood in the following terms: the soul (anima in Mancuso) is an evolutive step or phase of the human spirit. See David Monti, Moreno Fiori, Alessia Micoli, A'abisso del sé. Satanismo e sette sataniche (Milano: Giuffrè Editore, 2011), 28, n. 12.

\footnotetext{
${ }^{49}$ Mancuso, L'anima e il suo destino, 306-11.

${ }^{50}$ It is crucial to understand that Mancuso rethinks his entire theology, so virtually all doctrines are reconsidered. Simuț, Essentials of Catholic Radicalism, 21 and 137.
}

natural world, then faith in the God of traditional theology must be reassessed in the light of Hegel's discovery: faith is no longer directed towards an external entity but towards the internality of man's own spirituality. ${ }^{51}$ As Mancuso puts it, faith is no longer based on the authority of a supernatural God who reveals himself from outside but on the authenticity of man's natural existence in the material world which discloses itself from inside. ${ }^{52}$

This move from authority to authenticity is what defines Mancuso's perspective on faith as trust in man's capacity to see himself in what can be traditionally described as "divine" terms - as in Hegel $^{53}$ - while the concept of truth is no longer based on the revelation of God's supernatural being but on man's perception of reality as pertaining to the material world of nature. In other words, according to Mancuso, man must learn how to detach himself from external authorities, doctrines, and orthodoxy in order to embrace his own internal authenticity, practicality, and orthopraxis. ${ }^{54}$ Man must not rely on what other entities tell him - not any longer, but on what he understands to be correct, good, and practical for himself and others in the world. ${ }^{55}$

Thus, spirituality is not belief in a supernatural God and his/its external authority; it is the innermost conviction that man must do whatever it takes to live in truth, namely according to his own perception of reality, and in doing so he must behave ethically based on what he knows to be the truth as a result of his own rational assessment of the material reality of the

\footnotetext{
${ }^{51}$ See also Craig B. Matarrese, Starting with Hegel (London: Continuum, 2010), 156.

52 Vito Mancuso, Io e Dio (Milano: Garzanti Libri, 2011), 436.

${ }^{53}$ Daniel Berthold-Bond, Hegel's Grand Synthesis. A Study of Being, Thought, and History (Albany, NY: State University of New York Press, 1989), 26. 54 Vito Mancuso, Obbedienzà e libertà. Critica e
rinnovamento della coscienza cristiana (Roma: Fazi
Editore, 2012), 15.
}

${ }^{55}$ Mancuso, Io e Dio, 436-7. 
natural world. ${ }^{56}$ Man's subjective truth is much more important than the traditional objectivity of doctrines; nobody can dictate in man's life other than himself. He is the God of his own existence, so the only authority he must obey is the authority of his own rationality, goodness, and practicality; for Mancuso, this is the truth and the key to genuine authenticity. ${ }^{57}$ In other words, man must learn how to be human; man should no longer be interested in seeing himself in divine terms - such an approach belongs to the past and the external authority of the supernatural God of the Bible. These days, however, man must see himself as human because what matters for the present is the internal authenticity of man's natural existence in the world. Mancuso is convinced that this was exactly the message proclaimed by Christ and others; being human means being a true Christian according to Mancuso, but being a true Christian presupposes that man's authenticity - which is the core of his authority - is deeply rooted in the general consciousness of humanity. ${ }^{58}$ Thus, being a true Christian, Mancuso believes, means accepting all religions as true and authentic because what counts in the end is not the authority of certain external doctrines endorsed by a supernatural God, but the authenticity of man's own rational convictions supported by humanity's natural consciousness. The only God man can accept is himself and his own existence in the world; this is, for Mancuso, the key to genuine spirituality.

\section{Bibliography}

\section{Books}

Beiser, F., Hegel (New York: Routledge, 2005).

Berthold-Bond, D., Hegel's Grand Synthesis. A Study of Being, Thought, and History (Albany, NY: State University of New York Press, 1989).

\footnotetext{
${ }^{56}$ More about Hegel's ethics in Allen W. Wood, Hegel's Ethical Thought (Cambridge: Cambridge University Press, 1990, reprinted 1995), 228.

${ }^{57}$ Compare Petro Barcellona, 'Introduzione', in Alessandra Mallamo and Angelo Nizza (eds.), Polisofia (Roma: Edizioni Nuova Cultura, 2012), xvii-xxv, on xix-xx.

${ }^{58}$ Mancuso, Io e Dio, 440-6.
}

Brotto, F., Rileggendo Simone Weil (Firenze: Il Covile, 2011).

Cannatà, A., Eugenio Scalfari e il suo tempo. Un viaggio nelle idee di Scalfari e nei fatti, gli avvenimenti più importanti della recente storia d'Italia (Milano: Mimesis Edizioni, 2010).

Corsi, R., Facebook: figure e figurucce della decadenza (Roma: Armando Editore, 2009).

de Roberta, M., L'ordine del cuore. Etica e teoria del sentire (Milano: Garzanti Libri, 2012).

Desmond, W., Hegel's God. The Counterfeit Double? (Aldershot: Ashgate, 2003).

Firrao, F. P., Origini. Nascita della scienza moderna e nuove prospettive: laboratori didattici, ipotesi di percorso (Firenze: Leo S. Olschki, 2009).

Franceschelli, O., Darwin e l'anima. L'evoluzione dell'uomo e I suoi nemici (Roma: Donzelli Editore, 2009).

Garaventa, R., Religiosità senza dogmi. Ambiguità e prospetticità delle religioni storiche (Napoli: Orthotes Editrice, 2012).

Giorello, G., Senza Dio. Del buon uso dell'ateismo (Milano: Longanesi, 2010).

Lauer, Q., SJ, Essays in Hegelian Dialectic (Bronx, NY: Fordham University Press, 1977).

Lewis, T. A., Religion, Modernity, and Politics in Hegel (Oxford: Oxford University Press, 2011).

Mancuso, V., Il dolore innocente. L'handicap, la nature e Dio (Milano: Mondadori, 2002).

Mancuso, V., Io e Dio (Milano: Garzanti Libri, 2011).

Mancuso, V., L'anima e il suo destino (Milano: Raffaello Cortina Editore, 2007).

Mancuso, V., Obbedienzà e libertà. Critica e rinnovamento della coscienza cristiana (Roma: Fazi Editore, 2012).

Mancuso, V., Rifondazione della fede (Milano: Mondadori, 2005).

Mancuso, V., Hegel teologo e l'impardonabile assenza del «Principe di questo mondo» (Casale Monferrato: Piemme, 1996).

Matarrese, C. B., Starting with Hegel (London: Continuum, 2010).

Monti, D. Fiori, M., and Micoli, A., A'abisso del sé. Satanismo e sette sataniche (Milano: Giuffrè Editore, 2011).

Paolozzi, L. and Leiss, A., La paura degli uomini. Maschi e femine nella crisi della politica (Milano: Saggiatore, 2009).

Paradiso, M., Nell'intimo di Dio. La teologia trinitaria di Hans Urs von Balthasar (Roma: Città Nuova Editrice, 2009). 
Possenti, V., Il nuovo principio persona (Roma: Armando Editore, 2013).

Schlitt, D. M., Hegel's Trinitarian Claim: A Critical Reflection (Albany, NY: State University of New York Press, 2012).

Seri, F. P., Temi, problemi e aspetti del rapporto tra Dio e l'uomo (Roma: Armando Editori, 2013).

Sgubbi, G., L'intelligenza del mistero. Dialogo con Eberhard Jüngel (Roma: Città Nuova Editrice, 2000).

Simuț, C. C., Essentials of Catholic Radicalism. An Introduction to the Lay Theology of Vito Mancuso (Frankfurt am Main: Peter Lang, 2011).

Sozzi, L., Gli spazi dell'anima (Torino: Bollati Boringhieri Editore, 2011).

Taylor, C., Hegel (Cambridge: Cambridge University Press, 1975, reprinted 1999).

Urbinati, N., Prima e dopo. La brutta china della democrazia italiana (Roma: Donzelli Editore, 2011).

Veneziani, M., Dio, patria e famiglia dopo il declino (Milano: Mondadori, 2012).

Wood, A. W., Hegel's Ethical Thought Cambridge: Cambridge University Press, 1990, reprinted 1995).

\section{Newspaper Articles}

Mancuso, V., 'La religione civile che manca all'Italia', in La repubblica, 13 't January, 2009.

Follain, J., "Crowds Shrink for "Bland" Benedict, the Pope Who Only Says No', in Sunday Times, $4^{\text {th }}$ January, 2009.

\section{Journal Articles}

Annicchino, P., 'Laïcité as Civil Religion. An Italian American Perspective', The George Washington International Law Review 41.4 (2010): 817-26.

Simut, C. C., 'The Theology of Creation in Vito Mancuso's Radical Theology', Acta Theologica 31.1 (2011): 138-55.

\section{Book Chapters}

Barcellona, P., 'Introduzione', in Alessandra Mallamo and Angelo Nizza (eds), Polisofia (Roma: Edizioni Nuova Cultura, 2012), xvii-xxv.

Cardone, R., 'Calendario editoriale. Un decoder per il libro (batteries not included)', in Vittorio Spinazzola (ed.), Tirature 2010. Autori, editori, pubblico (Milano: Saggiatore, 2010), 202-15.

Cullen, B., 'Hegel on the Human and the Divine, in the Light of the Criticisms of Kierkegaard', in William Desmond (ed.), Hegel and His Critics: Philosophy in the Aftermath of Hegel (Albany, NY: State University of New York Press, 1989), 93-103.

Giorello, G., 'Libertarismo ovvero radicalismo senza radici', in Dario Antiseri and Giulio Giorello, Libertà. Un manifesto per credenti e non credenti (Milano: Bompiani 2008).

Mills, P. J., 'Hegel's Antigone', in Jon B. Stewart (ed.), The Phenomenology of Spirit Reader: Critical and Interpretative Essays (Albany, NY: State University of New York Press, 1998), 243-71.

\section{Internet Resources}

www.vitomancuso.it. 